ANUVA Volume 1 (1): 1-9, 2017

Copyright C2017, ISSN: 2598-3040 online

Available Online at: http://ejournal.undip.ac.id/index.php/anuva

\title{
Orientasi Diri Sebagai Usaha Pengembangan Profesi Pustakawan
}

\author{
Yuli Rohmiyati ${ }^{*}$ ) \\ ${ }^{I}$ Prodi Ilmu Perpustakaan, Fakultas Ilmu Budaya, Universitas Diponegoro \\ Jl. Prof. Soedarto,SH, Kampus Tembalang, Semarang. Indonesia \\ ${ }^{*}$ Korespondensi :yulirohmiyati@gmail.com
}

\begin{abstract}
The purpose of this study is to assess the self-orientation of a librarian as an attempt to float the profession. The research method used is with qualitative approach. Technique of collecting data by interview to the librarian achievement. The results of this study are self-oriented librarians illustrated from the advantages, disadvantages and achievements of librarians. The advantages identified in this study are Discipline, Clean (likes to be clean), All-round curious, High integrity to work and profession, Achieving in academic and work, Expert/ skilled in the field of librarianship, Always maintain appearance, Religious. Adaptive. Work hard. Flexible. Thorough, Self-evaluation, Adaptive, Working fast and efficiently, ability to convey ideas well in various media, often meet librarians, and Conduct publications and reportage. As for the lack of selfinformants is Too detailed explain something until people sometimes tired of listening, Too procedural, Sometimes want to win alone, Do not want to be disturbed if being working, nervous, impatient. And the librarian's self-presentation is depicted in fashion by wearing a short-sleeved shirt with a not-so-bright color, or wearing batik in dark colors and always using perfume in formal events with black pantopel shoes. fashion as a rule of life with formal clothes like office employees wear blazers and cuffs and bolero.
\end{abstract}

Keywords: Self-orientation, self surplus, lack of self, self-presentation, librarian, clothing, achievement

\begin{abstract}
Abstrak
Tujuan dari penelitian ini adalah untuk mengkaji orientasi diri seorang pustakawan sebagai sebuah usaha untuk mengambangkan profesi. Metode penelitian yang digunakan adalah dengan pendekatan kualitatif. Teknik pengumpulan data dengan wawancara kepada para pustakawan berprestasi. Hasil dari penelitian ini adalah orientasi diri pustakawan tergambar dari kelebihan, kekurangan dan prestasi para pustakawan. Adapun kelebihan yang berhasil diidentifikasi dalam penelitian ini adalah Disiplin, Bersih (suka akan kebersihan), Serba ingin tahu, Integritas tinggi terhadap pekerjaan dan profesi, Berprestasi dalam hal akademik dan pekerjaan, Ahli/ terampil dalam bidang kepustakawanan, Selalu menjaga penampilan, Religius. Adaptif. Bekerja Keras. Fleksibel. Teliti, Evaluasi diri, Adaptif, Bekerja cepat dan efisien, kemampuan menyampaikan gagasan dengan baik dalam berbagai media, sering bertemu pakar kepustakawanan, dan Melakukan publikasi dan reportase. Adapun kekurangan diri para informan adalah Terlalu detail menjelaskan sesuatu sampai orang kadang bosan mendengarkan, Terlalu prosedural, Terkadang ingin menang sendiri, Tidak mau diganggu jika sedang bekerja, nervous, kurang sabar. Dan presentasi diri pustakawan digambarkan dengan tata busana dengan mengenakan hem lengan pendek dengan warna yang tidak terlalu cerah, atau mengenakan batik dengan warna toska/ gelap dan selalu menggunakan parfum dalam acara formal dengan sepatu pantopel hitam. busana sebagai rule of life dengan baju formal layaknya pegawai kantoran pakai blazer dan manset serta bolero.
\end{abstract}

Kata Kunci : Orientasi diri; kelebihan diri; kekurangan diri; presentasi diri; pustakawan; tata busana; prestasi 


\section{Pendahuluan}

Orientasi diri merupakan peninjauan untuk menentukan sikap (arah, tempat, dan sebagainya) yang tepat dan benar; atau pandangan yang mendasari pikiran, perhatian atau kecenderungan (https://kbbi.web.id). Orientasi diri seorang pustakawan berarti peninjauan untuk menentukan sikap yang tepat dan benar sebagai seorang pustakawan, yang memiliki visi tentang kepustakawanan kedepan ysng dapat diambil sebagai sebuah model pustakawan unggulan yang akan dapat memperbaiki citra pustakawan.

Saat ini profesi pustakawan lambat laun terlihat mulai populer. Hampir semua instansi mulai dari lembaga pemerintahan, lembaga pendidikan, perusahaan dan instansi swasta membutuhkan pustakawan untuk mengelola pengetahuan dalam lembaga atau instansi tersebut.

Seiring dengan meningkatnya kebutuhan akan tenaga pustakawan maka pengakuan terhadap profesi tersebut pun menin gkat. Tetapi, sebagai sebuah profesi yang berkembang, masih banyak masukan dan kritik atas profesi tersebut. Diantaranya kritik atas diri pustakawan sendiri seperti gesture seorang pustakawan yang masih dianggap negatif, presentasi diri pustakawan yang masih minim dan berimbas pada layanan yang kurang maksimal.

Hal diatas memperlihatkan wajah pustakawan di Indonesia. Sehingga penelitian ini akan mengkaji tentang orientasi diri seorang pustakawan sebagai sebuah usaha untuk memperbaiki dan mengembangkan profesi pustakawan. Rumusan masalah dalam penelitian ini adalah bagaimana orientasi diri seorang pustakawan sebagai sebuah usaha untuk mengambangkan profesi tersebut. Dengan tujuan untuk mengkaji orientasi diri seorang pustakawan sebagai sebuah usaha untuk mengambangkan profesi.

Signifikansi penelitian

Signifikansi dari penelitian ini adalah

a. Mendapatkan gambaran tentang orientasi diri seorang pustakawan

b. Mengarahkan peta pengembangan profesi secara internal

c. Memperbaiki wajah profesi pustakawan agar dapat memberikan citra pustakawan 


\section{Kerangka Teori}

Kerangka teori dari penelitian ini adalah

Bagan 1. Kerangka teori

\section{Citra pustakawan}

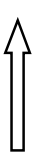

\section{Presentasi diri pustakawan}

Orientasi diri pustakawan

\section{Kelebihan diri dari profesi pustakawan}

2. Kekurangan diri dari profesi pustakawan

3. Prestasi yang dicapai

Self-presentation is behavior that attempts to convey some information about oneself or some image of oneself to other people. It denotes a class of motivations in human behavior. These motivations are in part stable dispositions of individuals but they depend on situational factors to elicit them. Specifically, self-presentational motivations are activated by the evaluative presence of other people and by others' (even potential) knowledge of one's behavior (Roy, 1987: 71-87)

Orientasi diri memotivasi tindakan seseorang, perkembangan nilai dan moral mengutamakan pemindahan (transmisi) nilai dan moral dari budaya masyarakat/ kelompok masyarakat kepada anggota masyarakat/ profesi yang memahami nilai dan norma yang terdapat dalam budaya masyarakat.Sejalan dengan pernyataan Hakam, 2007:131-132 sebagaimana tedapat dalam teori moral sosialication dari Hoffman (Rasid Yunus, 2013: 72)

Citra seorang pustakawan membaik jika orientasi diri seorang pustakawan baik. Orientasi diri dilakukan dengan cara melihat kekurang, kelebihan dan beberapa prestasi yang di 
dapatkan oleh diri seorang pustakawan tersebut. Kemudian presentasi diri akan baik jika orientasi diri sebagai faktor internal dalam memperbaiki citra pustakawan tersebut.

\section{Metode penelitian}

Metode penelitian yang digunakan adalah pendekatan kualitatif dengan metode wawancara. Pendekatan ini dipakai dengan tujuan untuk mendapatkan data yang fokus dan dalam sehingga tujuan dari penelitian ini tercapai.

Penelitian ini dilakukan di Kota Semarang dengan informan yang dapat menjawab pertanyaan penelitian peneliti. Informan tersebut adalah pustakawan yang telah memiliki jabatan fungsional pustakawan dan memiliki prestasi di bidang kerjanya.

\section{Hasil dan Pembahasan}

a. Orientasi Diri

Orientasi diri merupakan cara pandang seseorang pada dirinya sendiri. Orientasi diri sangat penting sebagai dasar perbaikan presentasi diri dan citra pustakawan. Orientasi diri seseorang akan baik jika individu tersebut cukup mengenal dengan baik dirinya, hal-hal yang dapat dipakai untuk melakukan orientasi diri adalah kelebihan diri, kekurangan diri dan prestasi diri.

Baik buruknya orientasi diri terkait dengan harga diri seseorang, dan harga diri tersebut akan terus meningkat jika banyak keberhasilan yang dicapai oleh seseorang. Tetapi jika individu tersebut sering mengalami kegagalan maka harga diri individu tersebut dapatlah semakin turun.

b. Kelebihan diri

Kelebihan diri merupakan identifikasi berbagai hal yang dipandang sebagai kelebihan dari seseorang.

Berdasarkan data penelitian yang diperoleh, kelebihan diri informan adalah sebagai berikut : 1. Disiplin, 2. Bersih (suka akan kebersihan), 3. Serba ingin tahu, 4. Integritas tinggi terhadap pekerjaan dan profesi, 5. Berprestasi dalam hal akademik dan pekerjaan, 6. Cumlaude, 7. Berprestasi, sebagai Juara 2 Pustakawan Berprestasi Terbaik Nasional Tahun 2014 dengan usia termuda yaitu pada usia 25 tahun, 8 . Tertarik/ hobby pada hal-hal yang berkaitan dengan Teknologi Informasi, 9. Dalam bidang kepustakawanan telah ahli dalam pengolahan koleksi, mahir dalam bidang digitalisasi dan multimedia, ahli dibidang pelayanan dan keanggotaan, 10. Selalu menjaga penampilan, 11. Terampil dan 12. Religius. 
Informan lain menyampaikan bahwa kelebihan dirinya adalah: memiliki kemampuan menganalisis kekurangan diri dan tim sehingga bisa memprediksi hal terburuk dalam hidup. "Alhasil saya bisa survive dalam kondisi apapun, dimanapun dan kapanpun" begitu penuturan informan.

Hasil wawancara selanjutnya, menurut informan "Adaptif adalah kelebihan lain dari saya. Saya mudah menyesuaikan diri kpd orang lain, lingkungan dan situasi \& kondisi yg berbeda dr sebelumnya".

"Karena saya baru bekerja. Saya hanya memiliki cerita 4 tahun pasca lulus kuliah. Setelah menyandang alumni Jurusan Ilmu Perpustakaan Undip, saya tertarik tidak bekerja di gedung perpustakaan karena terprovokasi dari orang lain lalu membuat motivasi bagi saya. Hasilnya, saya memiliki kemampuan bekerja cepat dan efisien berkat bekerja di YPPI".

"Karena saya suka bergaul dan suka mencoba hal baru, saya memiliki kemampuan menyampaikan gagasan dg baik dalam berbagai media (tulis dan video)".

"Saya sering bertemu pakar kepustakawanan, sehingga saya diberi motivasi untuk menjadi ilmuan. Lantas saya mengaplikasikannya dalam bentuk tulisan ilmiah maupun populer (paper, surat kabar, blog)".

"Lalu saya juga suka mengemas ulang informasi dalam bentuk reportasi berita tulis dan video menjadi citizen journalist televisi dan media daring".

"Saat ini saya bekerja di lembaga besar di perguruan tinggi. Saya seperti membuat pondasi di perpustakaan perguruan tinggi. Sehingga saya mempraktekkan kemampuan saya dalam memanagemen perpustakaan. Salah satunya yaitu membuat kategori bahan pustaka”.

Informan lain menyampaikan bahwa pribadi yang flexible dalam arti mudah menerima suatu keadaan dan tidak mempersulit keadaan. Mudah beradaptasi dengan lingkungan. cepat belajar, mempunyai karakter ingin tahu dan cepat menyerap pelajaran yang diberikan guru atau dosen. juga ambisius dan kritis. Menurut informan tersebut "Bagi saya jalan menuju kesuksesan diri adalah saat diri saya mengalami kegagalan, saya berdiri sendiri dan saya tidak mengizinkan orang lain mendirikan saya”.

Informan lain menyampaikan bahwa " saya termasuk teliti dalam mengerjakan maka saya menuntut mendekati kesempurnaan. Hal ini membuat badan saya lelah bekerja. Sehingga produktifitas tidak konsisten. Perlu waktu penyembuhan stamina yang lebih lama. 
"Jika saya suka bekerja pada bidang tertentu. Saya cenderung menjadi workaholic sehingga mengabaikan perhatian teman bahkan keluarga.

Rasa keingintahuan saya yang tinggi membuat saya suka mencoba hal baru sehingga saya tidak memiliki kemampuan yang dalam terhadap bidang tertentu. Seperti danau luas yang dangkal.

Berdasarkan hasil wawancara diatas dapat diidentifikasi bahwa kelebihan diri seorang pustakawan diantaranya adalah: 1. Evaluasi diri, 2. Adaptif, 3. Bekerja cepat dan efisien, 4. kemampuan menyampaikan gagasan dg baik dalam berbagai media, 5 . sering bertemu pakar kepustakawanan, 6. Aplikatif, 7. Melakukan publikasi dan reportase

c. Kekurangan diri

Kekurangan diri merupakan cara pandang seseorang pada dirinya sendiri yang menganggap sesuatu sebagai sebuah kelemahan.

Berdasarkan data yang diperoleh kekurangan diri dalam diri seorang pustakawan adalah : 1. Terlalu detail menjelaskan sesuatu sampai orang kadang bosan mendengarkan, 2. Terlalu prosedural, 3. Terkadang ingin menang sendiri, 4. Tidak mau diganggu jika sedang bekerja.

Informan lain menyampaikan bahwa kekurangan dirinya adalah (1) "Mungkin saya orang yang suka "nervous" dan mudah lupa juga, jadi saya bawa buku noted tiap hari dan mencatat apa yg perlu saya lakukan ( buat check list) biar gk lupa.

(2) Dalam pekerjaan saya harus selalu sabar, tapi saya kurang sabar. Saya pengen pekerjaan cepet selesai dan dalam bahasa jawa-nya gak tlaten. Mudah bosen juga.. Kalau harus mengulang-ulang sesuatu, (3) Saya tidak suka dengan rekan kerja yang lelet dalam bekerja dan itu membuat saya sebal tapi saya sembunyikan kesebalan saya, saya takut memberikan feedback pada rekan saya tersebut. (4) Untuk memberikan feedback kepada orang lain saya perlu belajar..karena hidup di negeri barat harus direct tidak perlu takut dan ragu-ragu dalam memberi feedback. Karena saya orang jawa yang suka indirect ( tidak langsung) takut menyinggung perasaan orang lain. Hal itu membuat saya harus extra dalam memerangi diri saya sendiri.

d. Prestasi diri 
Berdasarkan data yang diperoleh prestasi yang diraih adalah : 1. Juara 1 pustakawan berprestasi Tingkat Unissula tahun 2011, 2012 dan 2013, 2. Juara harapan 1 pustakawan berprestasi tingkat kopertis 6 jateng tahun 2012, 3. Juara 1 pustakawan berprestasi terbaik tingkat provinsi jawa tengah tahun 2014, 4. Juara 2 pustakawan berprestasi terbaik tingkat nasional tahun 2014, 5. Penghargaan Nugra jasadarma pustaloka sebagai pustakawan berprestasi tingkat nasional peringkat 2 .

Informan lain menyampaikan bahwa (1) Sejak mahasiswa Prestasi saya selain aktif menjadi pengurus aktif dan ketua di berbagai organisasi prodi, fakultas, universitas, regional, \& nasional, ada juga prestasi akademik yaitu (a) Juara 3 Lomba Karya Tulis Ilmiah Mahasiswa Fakultas (2011). (b) Menasbihkan diri sebagai pemenang Film Dokumenter Terbaik pada Lomba Temu Ilmiah Mahasiswa Nasional Mahasiswa Perpustakaan Se-Indonesia (2012) di Universitas Padjadjaran Bandung. (c) Dua tahun berturut Lolos Hibah Penelitian Mahasiswa Fakultas (2011-2012).

Informan lain menyampaikan bahwa "Saat bekerja di YPPI, saya aktif mempromosikan lembaga melalui 30 kegiatan literasi selama 2,5 tahun dengan terbit di media nasional dan internasional di televisi, cetak, maupun daring dan radio. Saat pindah bekerja di univ tidar. Saya aktif menulis di surat kabar dan ilmiah yang saya rangkum di https://untid.academia.edu/DickiAgusNugroho. Saya juga aktif menjadi citizen journalist di net tv, tvri dan rencana merambah ke trans7. Dan berkontribusi melakukan pengabdian masyarakat dengan mendirikan konsultan perpustakaan Rumah Cinta.

e. Presentasi diri

Presentasi diri

Berdasarkan data yang diperoleh terkait presentasi diri dalam hal bertata busana diketahui bahwa informan lebih senang mengenakan hem lengan pendek dengan warna yang tidak terlalu cerah, atau mengenakan hem slim fit yang tidak terlalu ketat, atau mengenakan batik dengan warna toska/ gelap dan selalu menggunakan parfum dalam acara formal dengan sepatu pantopel hitam.

Dalam hal komunikasi informan menggunakan bahasa yang formal untuk user dosen dan sesama staf perpustakaan. Dan jika berkomunikasi dengan user mahasiswa menggunakan bahasa semi formal.

Terkait gesture dan kontak mata, informan selalu berkomunikasi dengan melakukan kontak mata dan gesture yang baik seperti selalu menghadap kepada lawan bicara. 
Informan lain menyampaikan bahwa "Sejak akhir 2015 saya baru memahami busana sebagai rule of life: pandangan pertama itu penting. Maka saya memakai baju formal layaknya pegawai kantoran di jakarta. Ditambahkan biar semakin kelihatan muda menyesuaikan pemustaka adalah mahasiswa. Saya kadang pakai blazer dan manset serta bolero. Krn ada hari khusus olah raga pada jumat. Saya memakai celana jeans dan kaos polo. Wajah yg cerah selalu mjd urusan prioritas jika berminyak dengan pembersih muka. Tatanan rambut yg rapi menjadi urusan penting selanjutnya. Sepatu selalu yg kece dan kekinian dan tentunya matching dgn celana dan baju."

Dalam hal komunikasi dan gesture "Di kantor saya ada pembagian jadwal yaitu sebagai pelayanan sirkulasi dan pelayanan penelusuran informasi. Keduanya memakai gesture minimal gerak tangan saya untuk menunjukkan sesuatu dan tetap kontak mata."

Adapun cara yang dipakai untuk meningkatkan kualitas diri yaitu hard skill, soft skill dan spiritual skill. Hard skill yang ditingkatkan adalah : (a) belajar materi kepustakawanan setiap bulan sekali. Lalu langsung saya praktekkan. Misalnya tentang liaison librarian yang saya langsung praktekkan menjadi asisten kegiatan penelitian dan pengabdian dosen. (b) Belajar metodologi. Caranya dengan langsung menulis paper dan dipublikasikan.

Softskill yang ditingkatkan : (a) berangkat kerja lebih awal. Supaya menjadi budaya baik dan ditiru teman kerja. (b) Mengatakan hal-hal yang baik dan terstruktur sehingga bisa di tiru teman kerja contohnya ketika sedang pelayanan sirkulasi seperti "ada yg bisa saya bantu, kakak? " Kadang menyapa dengan "Selamat pagi dan selamat menikmati perpustakaan". "Silahkan mendaftar anggota. Bisa dibantu - nomor induknya berapa?" (c) Jika diberi instruksi kerja. Maka langsung saja jawab "bisa" lalu dikerjakan. Selesai atau tidak selesai maka laporkan. Cara softskill dan hardskill itu saya rasakan telah meningkatkan kepercayaan dosen dan tendik kepada pustakawan. Cara terakhir adalah perlu upgrade batiniyah. Sehingga perlu lebih dekat kapada agama.

\section{Simpulan}

Simpulan dari penelitian ini adalah orientasi diri pustakawan tergambar dari kelebihan, kekurangan dan prestasi para pustakawan. Adapun kelebihan yang berhasil diidentifikasi dalam penelitian ini adalah Disiplin, Bersih (suka akan kebersihan), Serba ingin tahu, Integritas tinggi terhadap pekerjaan dan profesi, Berprestasi dalam hal akademik dan 
pekerjaan, Ahli/ terampil dalam bidang kepustakawanan, Selalu menjaga penampilan, Religius. Adaptif. Bekerja Keras. Fleksibel. Teliti, Evaluasi diri, Adaptif, Bekerja cepat dan efisien, kemampuan menyampaikan gagasan dengan baik dalam berbagai media, sering bertemu pakar kepustakawanan, dan Melakukan publikasi dan reportase. Adapun kekurangan diri para informan adalah Terlalu detail menjelaskan sesuatu sampai orang kadang bosan mendengarkan, Terlalu prosedural, Terkadang ingin menang sendiri, Tidak mau diganggu jika sedang bekerja, nervous, kurang sabar. Dan presentasi diri pustakawan digambarkan dengan tata busana dengan mengenakan hem lengan pendek dengan warna yang tidak terlalu cerah, atau mengenakan batik dengan warna toska/ gelap dan selalu menggunakan parfum dalam acara formal dengan sepatu pantopel hitam. busana sebagai rule of life dengan baju formal layaknya pegawai kantoran pakai blazer dan manset serta bolero.

\section{Daftar Pustaka}

Roy F. Baumeister, Debra G. Hutton. Self-Presentation Theory: Self-Construction and Audience Pleasing. https://link.springer.com/chapter. Dalam Brian Mullen, George R. Goethals. 1987. Theories of Group Behavior pp 71-87.

https://kbbi.web.id/

Rasid Yunus. 2013. Transformasi Nilai-Nilai Budaya Lokal Sebagai Upaya Pembangunan Karakter Bangsa (Penelitian Studi Kasus Budaya Huyula di Kota Gorontalo). Jurnal Penelitian Pendidikan, $\quad$ Vol. $\quad 14 \quad$ No. $1, \quad$ April 2013https://s3.amazonaws.com/academia.edu.documents. 